\title{
Three types of semiotic indeterminacy in Monod's philosophy of modern biology
}

\author{
Stefan Artmann \\ Institute of Philosophy, Friedrich Schiller University, \\ Zwätzengasse 9, 07740 Jena, Germany \\ e-mail: stefan.artmann@uni-jena.de
}

\begin{abstract}
Synthesizing important research traditions in information theory, structuralist semiotics, and generative linguistics, at least three main types of semiotic indeterminacy must be distinguished: Kolmogorov's notion of randomness defined as sequential incompressibility, de Saussure's principle of contingency of sign which ensures the possibility of translation between different sign systems, and Chomsky's idea of indefiniteness in generative mechanisms as a requirement for the explanation of semiotic creativity. These types of semiotic indeterminacy form an abstract system useful for the description of concrete sign processes in their syntactic, semantic, and pragmatic dimension. In his philosophical reflections on modern biology, Jacques Monod used the conceptual opposition chance versus necessity to analyse several phenomena of indeterminacy (especially in molecular biology). The biosemiotic approach to life permits to apply the suggested system of semiotic indeterminacy on these phenomena.
\end{abstract}

Larvatus prodeo

The semantic field of indeterminacy is of great importance for modern science. Without notions like randomness, contingency, indefiniteness, probability, and undecidability, it would be impossible to formulate central findings of logic, information theory, semiotics, quantum physics, biology, sociology, etc. So this semantic field extends across the borders between natural, structural, and cultural sciences. 
Biosemiotics can profit from an intense reception of the multifarious explorations of indeterminacy in modern science. Systematically, it is necessary to build up an abstract system of different types of semiotic indeterminacy that can be applied to the analysis of concrete sign processes. Historically, the philosophical reflections on modern biology that were made in the so called "French school of molecular biology" (Fantini 1988: 14) are rich in interesting ideas for the biosemiotic exploration of indeterminacy.

A close reading of Jacques Monod's Le hasard et la nécessité (Monod 1970) shows that Monod reflects on three different kinds of hasard which can be co-ordinated within the semiotic dimensions of syntax, semantics, and pragmatics (1). These types of indeterminacy should be defined with the help of information theory, structuralist semiotics, and generative grammar, respectively (2). I have to concentrate on the first two types, randomness and contingency (2.1 and 2.2), and can only hint at some aspects of the third type, indefiniteness (3).

At its first publication in 1970, Monod's Le hasard et la nécessité has stirred up a heated debate about the philosophical premises and consequences of molecular biology. In the centre stood Monod's thesis that life results from a very improbable event (Monod 1970: 62 ). I do not want to reanimate the great hubbub that arose around this special kind of tychism and its existentialistic looks. Instead, I propose to analyse the use of the expression hasard in Monod's natural philosophy because here, semiotics can show its relevance to theoretic biology.

The conceptual structure underlying the use of the expression hasard in Monod's natural philosophy consists of three main elements.

Monod encounters the first type of indeterminacy in the primary structure of proteins. This structure is built up as a sequence of amino acids the order of which is au hasard (Monod 1970: 127): if the linear succession of 199 amino acids in a chain of 200 is well known, no rule exists to predict the last one. This kind of unpredictable structure I will call random. 
The second type of indeterminacy shows up in Monod's discussion of the genetic code. He comes to the following conclusion: it seems to be very probable that this code is chimiquement arbitraire (Monod 1970: 182), because no stereochemical reason can be given for the selection of a certain codon in the DNA to codify a certain amino acid in the primary structure of a protein. This kind of missing motivation I will call contingent.

Naturally, Monod does not intend to say that the biosynthesis of a protein is an ad hoc process when he underlines the importance of randomness and contingency. On the contrary! According to Monod, the highly invariable primary structure of a protein results, directly or indirectly, from the whole history of the biosphere. But exactly because of this thoroughly historical causality, it is impossible to decipher the biochemical function of a protein from its primary structure (Monod 1970: 128f). We can state the same in respect to the contingency of the relation between an amino acid and its encoding in the DNA: in a diachronic perspective, the concrete sign functions result from historical processes which cannot be fully specified only with the knowledge of their end-products. Analogously it must be said that even in a synchronic perspective, the knowledge of the chemical structure of the codons on the one hand and of the amino acids on the other hand is not enough to deduce the whole mechanism that connects these two sides. This third kind of a posteriori I will call indefinite.

For Monod, these three types of indeterminacy are primarily no reflections of the limits of biological knowledge but inhere in the ontological structure of life itself (Monod 1970: 148ff). The sequence of amino acids in a protein is random, the codon for an amino acid is contingent, and the functionality of a protein is indefinite. In the light of Monod's natural philosophy, a possible semiotic exploration of these phenomena of indeterminacy would by no means be an analysis of biological discourse but a research directed towards the objects of biology.

The next step in such a semiotic exploration must define the notions of randomness, contingency, and indefiniteness in more formal terms. The distinction between syntax, semantics, and pragmatics provides us with a useful framework hereto. ${ }^{1}$ For the purpose of

\footnotetext{
${ }^{1}$ Cf. Cariani (1998) on the distinction between syntax, semantics, and pragmatics as a general framework for biosemiotics.
} 
analysing Monod, I propose the following definitions of these semiotic dimensions that differ from the classical ones of Charles Morris (1938), insofar as their conceptual base is the Hjelmslevian notion of the sign function as a relation between different semiotic planes (Hjelmslev 1993). ${ }^{2}$

A sequence of semiotic objects is investigated syntactically when neither the possible inner sign functionality of the elements of the sequence nor possible sign functions between this sequence and other ones are considered. The main abstract syntactic characteristic of semiotic objects is the order in which their elements follow one after the other. Information theory is mostly interested in this one-sided linearity.

Semantically, the connections between different semiotic planes are decisive. These relations can be registered in the single elements of one sequence as sign functions between a form of expression and a form of content. But sign functions can also be described between different sequences, whether they are internally sign-functional or not.

The main abstract semantic characteristic of semiotic objects is their functionality. Structural semiotics has focused on these biplanar phenomena.

When the generation of semiotic objects is scrutinized, their pragmatic dimension comes into play. Such an exploration should be directed towards the interplay of syntax and semantics. The main abstract pragmatic characteristic of semiotic objects is their processual quality. Generative grammar is an important example of this kind of research although the name of this theory seems to designate only syntactic studies. But generative grammar describes one special semiotic competence as a capability to build up syntactically ordered sign functions so that this process works like an interface between expression plane and content plane (Chomsky 1988).

The three notions of indeterminacy found in Monod's natural philosophy can be mapped onto the semiotic dimensions of syntax, semantics, and pragmatics.

The randomness of the primary structure of proteins is of syntactic form: only the linear order of the chain of amino acids is involved in the statement that the question after the 200th element in the primary

${ }^{2}$ Cf. Chebanov (1999) for another biosemiotic use of glossematics. 
structure of a protein cannot be answered only with the knowledge of the previous 199 elements.

Contingency is a semantic phenomenon: the chemical structure of a DNA codon cannot be inferred from the chemical structure of the encoded amino acid and vice versa. So there are two different planes (a plane of expression manifested by the DNA sequence and a plane of content manifested by the primary structure of the protein ${ }^{3}$ ), and no motivation for the specific connections between their elements in terms of one plane or the other can be found.

Indefiniteness is pragmatic indeterminacy. The knowledge of the two planes of the sign function between the primary structure of a protein and the encoding in the DNA is not enough for specifying either all the processes that build up the linearity of the protein and of the encoding, or all the processes that lead to the biplanarity of the sign function, both in a diachronic or in a synchronic perspective. And exactly this is meant by indefiniteness.

\section{2}

It is necessary to fix the still loose coupling between Monod's types of indeterminacy and the three semiotic dimensions. In the following, this will be done for randomness and contingency. Andrei N. Kolmogorov's information-theoretic concept of randomness cannot only sharpen Monod's description of syntactic indeterminacy but will also help to indicate the limits of information-theoretic models for biological phenomena (2.1). Thereafter, the structuralist concept of the sign is applied to analyse Monod's semantic indeterminacy. In the semiotic tradition, Ferdinand de Saussure's principle of arbitrariness of sign and Roman Jakobson's postulate of universal translatability are the main references hereto (2.2).

${ }^{3}$ In Hjelmslevian semiotics, the expressions expression and content are "arbitrære" (Hjelmslev 1993: 55). They are used only to distinguish terminologically between the two planes contracting a sign function. Therefore, it would be equally possible to write: a plane of expression manifested by the primary structure of the protein and a plane of content manifested by the DNA sequence. 
The decisive idea for defining indeterminacy on one semiotic plane comes from the information-theoretic work of Kolmogorov that meanwhile developed into the theory of algorithmic information.

To define the randomness of a sequence of semiotic objects, first of all it is necessary to introduce the notion of the complexity of such a sequence. The Kolmogorov complexity of a semiotic sequence is the length of the shortest program that could produce the sequence in question as an output of an abstract automaton (like a universal Turing machine). The sequence is random when its complexity is approximately equal to its length. In the view of Kolmogorov, randomness means that we practically cannot compress a sequence by its algorithmic representation because a random sequence shows no or only negligible inner regularities. In comparison with the bit-length of such regularities, the program generating them would be describable with decisively fewer bits (Kolmogorov 1969).

Monod's example of syntactic indeterminacy is a paradigm of randomness in the sense of Kolmogorov complexity. That the 200th amino acid in the primary structure of a protein cannot be predicted even when the first 199 amino acids are well known, is only a more concrete way of saying that there are no algorithmically compressible regularities in the primary structure.

But Kolmogorov complexity not only permits a formalization of syntactic indeterminacy. In a meta-theoretic perspective, this concept can also be used to disprove Monod's assumption that he has shown the impossibility of finding some regularities in the primary structure of a protein (Monod 1970: 127). Here, we have to employ an incompleteness theorem of the computer scientist Gregory J. Chaitin who has developed the theory of algorithmic complexity into a prosperous meta-mathematical discipline.

Chaitin's incompleteness theorem indicates the following limit of information-theoretic reasoning: the proposition that a sequence has a Kolmogorov complexity greater than a certain fixed value cannot be proved in a formal axiomatic system with a Kolmogorov complexity smaller than this value (Chaitin 1974). ${ }^{4}$

${ }^{4}$ More precisely: a formal axiomatic system with Kolmogorov complexity greater than $K$ plus a constant (dependent on the automaton that implements the system) is needed to generate the set of all theorems stating that a sequence has Kolmogorov 
The drastic consequence of this theorem for Monod's philosophy was drawn by Bernd-Olaf Küppers. The assumed impossibility of disproving the randomness of the primary structure of a protein is itself unprovable in the framework of a formal system that has a Kolmogorov complexity smaller than the one of the primary structure. Küppers argues that to find by chance in the set of more than $2^{K}$ possible sequences the right one that proves as a codification of a formal system the randomness of another sequence with Kolmogorov complexity $K$, is very improbable (Küppers 1990: 100ff). A second way to formulate this improbability goes as follows. The chances to find an algorithm as a formal model for the evolution of a primary structure are very small because the sequence in question may be supposed as of tremendous complexity when described on the level of specification necessary to include algorithmically every kind of known natural law that could generate regularities in the sequence. It follows again that for all practical purposes, the construction of a formal system with the necessary complexity for a proof of randomness of primary structure is not feasible.

Küpper's meta-theoretic critique of Monod is not the consequence of an information-theoretic a priori but of a natural a posteriori: when the complexity of a system has grown in its history, it is conceivable that the randomness of its initial state could be deduced from its description at a later time. The more it is amazing that one important application of Kolmogorov complexity on the object level of biology follows an information-theoretic a priori reasoning.

Chaitin's struggle for an algorithmic theory of evolution based on Kolmogorov complexity shows the impossibility of reducing the evolutionary process to syntactic processes. Even in a very simple model of evolution proposed by Chaitin, he must introduce a semantic criterion through the backdoor: syntax is not enough.

Chaitin describes a computable sequence of rational numbers leading in the infinite limit to an uncomputable infinitely complex number called Omega as an "abstract example of evolution" (Chaitin

complexity $N$ (for all $N$ smaller than or equal to $K$ ) and of all theorems stating that a sequence has a Kolmogorov complexity greater than $K$ (Chaitin 1974: theorem 4.3). 
1988: 317). Chaitin's Omega number is the famous halting probability of a universal Turing machine. Alan Turing has proven in 1936 that this halting probability is not computable (Turing 1936): it is a random real number with infinite Kolmogorov complexity. So Omega can be seen as the limit of a computable sequence of rational numbers that converges to Omega uncomputably slowly.

It is not surprising at all that the rational numbers in this sequence will have an ever increasing Kolmogorov complexity. What Chaitin, however, is interested in, is the complexity of the first $K$ bits of each of the rational numbers because at some time the Kolmogorov complexity of these first $K$ bits will not fall under the threshold value of $K$ bits.

How is the sequence of rational numbers converging to Omega built up? Chaitin constructs the Nth approximation of Omega as follows: "One merely considers all programs up to $N$ bits in size and runs each member of this finite set of programs for $N$ seconds on the standard universal Turing machine. Each program $K$ bits long that halts before its time runs out contributes measure $2^{-K}$ to the halting probability Omega" (Chaitin 1988: 317). A non-syntactic criterion is present here at a very important position: every program $N$ bits in size has the chance to run $N$ seconds on the universal Turing machine. This cannot be justified in pure syntax; the time limit is of pragmatic nature: we cannot wait till infinity for the halting of a program.

For biosemiotics, there is more to get out of Chaitin's algorithmic model of evolution. In its finite version, a computable infinite sequence of strings with a fixed length of $N$ bits is determined as an approximation to Omega. Then, there exists a time $t$ after which the strings will not alter any more. These strings have a Kolmogorov complexity not less than $N$ bits because they cannot be computed by any program shorter than $N$ bits in less than $t$ seconds. Chaitin remarks that in some respect the $N$ bits of information of the strings generated at time $t$ and later "are coming from $t$ itself" (Chaitin 1988: 318). These $N$ bits are simulating the first $N$ bits of the halting probability Omega, and the time $t$ encodes the information about how long we have to wait till seemingly knowing them.

Information-theoretically, such a source of normally not accessible information is called an oracle (Chaitin 1977). This diviner has a genuinely semantic function. It connects a syntactic sequence (like a string of $N$ bits in Chaitin's finite model for evolution) to another one 
(like the first $N$ bits of the halting probability) that cannot be computed anyhow from the first sequence. But this first sequence can act as an expression of the second one so that the second sequence is the content of the first one. In Chaitin's evolutionary model, this sign functionality really strikes the eye: the first sequence is computable, the second one is uncomputable, so the second sequence cannot be deduced from the first one, but the first sequence can stand for the second one when we have established the time $t$ as a non-syntactic criterion. ${ }^{5}$

Ferdinand de Saussure has recognized the absent mutual deducibility of two nevertheless connected planes as the essence of the sign. Although the exact meaning of de Saussure's first sign-theoretic principle, l'arbitraire du signe (Saussure 1967: 100), has been and still is the object of an intense debate in semiotics, I think that the Danish glossematician Niels Ege has correctly analysed de Saussure's notion of contingency. ${ }^{6} \mathrm{He}$ distinguishes two perspectives on the sign. Seen from the outside, a sign is presupposing a whole system of signs and vice versa, so in this respect a sign, as an element of a semiotic system, is not contingent. But seen from the inside, the relation between a given expression and a given content is not motivated by either plane and, therefore, is contingent in the sense of de Saussure (Ege 1970: 26).

From this double perspective, it is possible to recognize another version of de Saussure's insight into semantic indeterminacy. In his essay On linguistic aspects of translation, Roman Jakobson (1971) formulates a principle of universal translatability. Understanding a sign, means to be able to translate it into another sign not necessarily of the same semiotic system but also of other such systems. Therefrom does not follow that there normally exists a one-to-one correspondence between both signs. But when we permit, for example, different lengths of the involved sequences, we can say that what is semiotic, is translatable.

${ }^{5}$ Here, Küpper's conjecture: semantic structures are syntactically random (Küppers 1996: 213f), is within reach. In a semiotic way, it should be formulated as follows: syntactic sequences entering a sign function are Kolmogorov random with respect to each other.

${ }^{6}$ I use the term contingency rather than arbitrariness because of Lacan's right criticism of the second expression (Lacan 1975: 23, 32, 41). 
In respect to the sign function, de Saussure's principle of contingency designates the same semiotic fact as Jakobson's principle of translatability: a sign is translatable because its inner relation between an expression and a content is contingent in spite of the determination of the sign by its semiotic system; and the relation between an expression and a content establishing a sign is contingent because the resultant sign is translatable from one semiotic system into another.

By showing itself as translatability, contingency is the main semantic premise for the growth of semiotic freedom (Hoffmeyer 1996). To discuss this evolutionary process in-depth, it seems necessary to look upon its pragmatic dimension. What biosemiotic insights can we await here that go beyond those in the syntactic and in the semantic dimension?

Our description of pragmatic indeterminacy in Monod's natural philosophy has shown that we have to search for an answer by scrutinizing the processual indefiniteness in the generation of syntactic and semantic structures. For biosemiotics, the main theoretic reference for this kind of research is evolutionary theory. In a Darwinian framework, we should await important hints especially from the subtheory of natural selection because there, the very historicalness of evolution must be explained (Maynard Smith 1993: 42).

Abner Shimony has underlined that the theory of natural selection has no general principles of its own which could not be derived from propositions of the evolutionary subtheories of variation and heredity (Shimony 1989). Stripped bare to their respective formal structure, variation means the exchange of an element at one position in a sequence that does not necessarily imply any functional relation to another sequence, whereas inheritance per se designates a functional relation between different sequences. Now Shimony writes,

I construe the neo-Darwinians as trying to say meta-theoretically that the evolution of the biosphere, subsequent to the establishment of the genetic code, is governed by the principles of heredity and variation and the laws of physics, and is constrained by biological and environmental boundary and initial conditions, but not constrained otherwise: within these constraints let happen what happens. (Shimony 1989: 229; emphasis by Shimony) 
If we accept this description, then for biosemiotics the neo-Darwinian research program is a conceptual experiment upon the radicalization of pragmatic indeterminacy. Why radicalization?

Pragmatic indeterminacy was defined as the unsurmountable indefiniteness of forms possibly occurring in the generation of syntactic and semantic structures. And the background of definiteness with which this indefiniteness contrasts, consists of the syntactic and the semantic dimension, their indeterminacies included. If selection, as a pragmatic phenomenon, is the process of establishing syntactic and semantic structures, and if Shimony is right to see selection as a result of variation, inheritance, and some boundary conditions, then pragmatics is nothing else than the interplay of syntax and semantics in certain contexts. With respect to the three types of indeterminacy, this means that pragmatic indefiniteness occurs when syntactic randomness and semantic contingency meet under certain conditions. No further pragmatic constraints on such events should be awaited; or, as Monod has put it, pragmatic indeterminacy is essentiel (Monod 1970: 149).

\section{References}

Cariani, Peter 1998. Life's journey through the semiosphere. Semiotica 120(3/4): 243-257.

Chaitin, Gregory J. 1974. Information-theoretic limitations of formal systems. Journal of the ACM 21: 403-424. Cited after reprint in: Chaitin 1990: 171-196.

- 1977. Program size, oracles, and the jump operation. Osaka Journal of Mathematics 14: 139-149. Cited after reprint in: Chaitin 1990: 207-215.

- 1988. Algorithmic information and evolution. In: Chaitin 1990: 314-319.

- 1990. Information, Randomness and Incompleteness: Papers on Algorithmic Information Theory. 2nd ed. Singapore: World Scientific.

Chebanov, Sergey V. 1999. Biohermeneutics and hermeneutics of biology. Semiotica 127(1/4): 215-226.

Chomsky, Noam 1988. Language and the Problems of Knowledge. Cambridge: MIT Press.

Ege, Niels 1970 [1949]. Le signe linguistique est arbitraire. In: Cercle Linguistique de Copenhague (ed.), Recherches Structurales. 2nd ed. (Travaux du Cercle Linguistique de Copenhague 5.) Copenhagen: Nordisk Sprog- og Kulturforlag, 11-29. 
Fantini, Bernardino 1988. La formation d'un intellectuel. In: Monod, Jacques, Pour une éthique de la connaissance. Paris: Découverte, 5-49.

Hjelmslev, Louis 1993 [1943]. Omkring Sprogteoriens Grundlaggelse. (Travaux du Cercle Linguistique de Copenhague 25.) Copenhagen: The Linguistic Circle of Copenhagen.

Hoffmeyer, Jesper 1996. Signs of Meaning in the Universe. Bloomington: Indiana University Press.

Jakobson, Roman 1971 [1959]. On linguistic aspects of translation. In: Jakobson, Roman, Selected Writings, vol. 2. The Hague: Mouton, 260-266.

Kolmogorov, Andrei Nikolaevich 1993 [1969]. To the logical foundations of the theory of information and probability theory. In: Shiryayev, A. N. (ed.), Selected Works of A. N. Kolmogorov, vol. 3. Translated by Sossinsky, A. B. (Mathematics and its Applications: Soviet Series 27.) Dordrecht: Kluwer, 203-207.

Küppers, Bernd-Olaf 1990. Information and the Origin of Life. Cambridge: MIT Press

- 1996. Der semantische Aspekt von Information und seine evolutionsbiologische Bedeutung. Nova Acta Leopoldina NF 72(294): 195-219.

Lacan, Jacques 1975 [1972/73]. Le Séminaire. Livre 20. Encore. Edited by Jacques-Alain Miller. Paris: Seuil.

Maynard Smith, John 1993 [1958]. The Theory of Evolution. Cambridge: Cambridge University Press.

Monod, Jacques 1970. Le hasard et la nécessité. Essai sur la philosophie naturelle de la biologie moderne. Paris: Seuil.

Morris, Charles W. 1938. Foundations of the Theory of Signs. International Encyclopaedia of Unified Science vol. 1(2). Chicago: University of Chicago Press.

Saussure, Ferdinand de 1967 [1916]. Cours de linguistique générale. Mauro, Tullio de (ed.). Paris: Payot.

Shimony, Abner 1989. The non-existence of a principle of natural selection. Biology and Philosophy 4: 255-273 and (Reply to Sober) 281-286. Cited after the reprint in: Shimony 1993: 228-252.

- 1993. Search for a Naturalistic World View, vol. 2. Cambridge: Cambridge University Press.

Turing, Alan M. 1936. On computable numbers with an application to the Entscheidungsproblem. Proceedings of the London Mathematical Society, ser. 2, 42: 230-265. 


\section{Три типа семиотической неопределенности} в философии современной биологии Моно

Синтезируя важнейшие исследовательские традиции в теории информации, структуралистской семиотике и генеративной лигвистике, нужно различать по крайней мере три главных типа семиотической неопределенности: понятие слуайности у Колмогорова, дефинированное через несократимость последовательностей; принцип арбитрарности знака у Соссюра, делающий возможным переводимость между разными знаковыми системами и принцип индефиниции генеративных механизмов Хомского, что является предпосылкой семиотической креативности. Эти типы семиотической неопределенности составляют абстрактную систему, которую можно использовать при описании конкретных знаковых процессов в синтаксическом, семантическом и прагматическом измерениях соответственно. Анализируя в своих философских работах разные феномены непоределенности (особенно в молекулярной биологии), Жак Моно пользовался концептуальным противопоставлением между случайностью и необходимостью. Биосемиотический подход к жизни позволяет при изучении этих феноменов использовать предлагаемую систему семиотической неопределенности.

\section{Semiootilise määramatuse kolm tüüpi Monod' kaasaegse bioloogia filosoofias}

Sünteesides olulisi uurimistraditsioone informatsiooniteoorias, strukturalistlikus semiootikas ja generatiivses lingvistikas, tuleb eristada vähemalt kolme peamist tüüpi semiootilist määramatust: Kolmogorovi juhuslikkuse mõistet, mis on defineeritud järgnevusliku koondamatuse kaudu, de Saussure'i märgi suvalisuse põhimõtet, mis võimaldab tõlgitavust erinevate märgisüsteemide vahel, ja Chomsky generatiivsete mehhanismide indefiniitsuse ideed, mis on semiootilise loovuse seletamise tingimuseks. Need semiootilise määramatuse tüübid moodustavad abstraktse süsteemi, mida on võimalik kasutada konkreetsete märgiprotsesside kirjeldamiseks vastavalt süntaktilistes, semantiliste ja pragmaatilistes mõõdetes. Oma kaasaegse bioloogia ainelistes filosoofilistes käsitlustes on Jacques Monod kasutanud kontseptuaalset vastandust juhuslikkuse ja paratamatuse vahel, analüüsimaks mitmeid määramatuse fenomene (iseäranis molekulaarbioloogias). Elu biosemiootiline käsitlusviis lubab nende fenomenide puhul rakendada väljapakutud semiootilise määramatuse süsteemi. 